\title{
Hsp90 Inhibition Reduces TLR5 Surface Expression and NF- $\kappa$ B Activation in Human Myeloid Leukemia THP-1 Cells
}

\author{
Bon Hyang Na, Thi Xoan Hoang $(D$, and Jae Young Kim $(\mathbb{D}$ \\ Department of Life Science, Gachon University, Seongnam, Gyeonggi-do 461-701, Republic of Korea \\ Correspondence should be addressed to Jae Young Kim; jykim85@gachon.ac.kr
}

Received 2 October 2017; Revised 7 January 2018; Accepted 17 January 2018; Published 14 February 2018

Academic Editor: Hannes Stockinger

Copyright (C) 2018 Bon Hyang Na et al. This is an open access article distributed under the Creative Commons Attribution License, which permits unrestricted use, distribution, and reproduction in any medium, provided the original work is properly cited.

\begin{abstract}
Tumors highly express active heat shock protein 90 (Hsp90), which is involved in tumor survival and progression. Enhanced Toll-like receptor (TLR) 5 expression and signaling were reported to be associated with acute myeloid leukemia. In the present study, we investigated the possible modulatory effects of Hsp90 inhibitors on TLR5 expression and signaling in the human myeloid leukemia cell line THP-1. Cells were pretreated with various concentrations of the Hsp90 inhibitor geldanamycin (GA) or the Hsp70 inhibitor VER155008, followed by stimulation with bacterial flagellin. Flagellin-induced nuclear factor- $\kappa$ B (NF- $\kappa$ B) activation was significantly reduced by treatment with GA or VER155008. To elucidate the underlying mechanism of this effect, mRNA and cell surface expression of TLR5 was examined. TLR5 mRNA expression was enhanced by both GA and VER155008, whereas cell surface expression of TLR5 was reduced by three different Hsp90 inhibitors, including GA, 17-(allylamino)-17-demethoxygeldanamycin, and radicicol, and an Hsp70 inhibitor. The inhibitory effect of Hsp90 inhibitors was much higher than that of Hsp70 inhibitor. Our results suggest that Hsp90 inhibitors suppress TLR5 surface expression and activation of NF- $\kappa$ B in THP-1 cells in response to TLR5 ligand, and these inhibitory effects may be associated with the possible mechanisms by which Hsp90 inhibitors suppress myeloid leukemia.
\end{abstract}

\section{Introduction}

Heat shock proteins (Hsp), including Hsp90, are highly abundant and ubiquitous molecular chaperones that help maintain the stability of proteins and target the degradation of unfolded proteins when cells are exposed to heat shock or other kinds of stress [1-3]. In addition to its role in protein folding, Hsp90 contributes to various cellular processes such as signal transduction and transportation of target protein $[4,5]$. Hsp90 is widely expressed and exists as a latent and uncomplexed form in eukaryotic normal cells. In contrast, tumors highly express active Hsp90 as a complex with oncogenic client proteins [6]. Hsp90 exhibits antiapoptotic functions and stabilizes many kinases involved in cancer-cell signaling [7-9]. Since Hsp90 inhibition can influence many proteins and block signaling pathways involved in tumor survival and progression $[10,11]$, Hsp90 inhibitors have been considered as good antitumor agents, and some inhibitors have been investigated in clinical studies $[12,13]$.
Toll-like receptors (TLRs) are germline-encoded patternrecognition receptors that play a crucial role in the first line of host defense by sensing pathogen-associated molecular patterns (PAMPs) [14]. Once TLRs recognize PAMPs, they serve as an important link between innate and adaptive immune responses by triggering the production of proinflammatory cytokines through the nuclear factor- $\kappa \mathrm{B}$ (NF- $\kappa \mathrm{B}$ ) pathway, which is an essential signal transduction cascade in inflammatory responses [15]. However, while TLR signaling is important for normal immune response, enhanced or aberrant TLR activation is associated with ineffective hematopoiesis and hematopoietic malignancy $[16,17]$. More notably, enhanced expression of the components of the TLR signaling pathway is associated with myelodysplastic syndromes [18-23]. Two studies have demonstrated that enhanced TLR5 expression and signaling are associated with acute myeloid leukemia [24] and multiple myeloma [25].

The purpose of this study was to investigate the possible modulatory effects of Hsp90 inhibitors on TLR5 expression 
and NF- $\kappa$ B activation in human myeloid leukemia THP-1 cells.

\section{Materials and Methods}

2.1. Cell Culture. Human monocytic THP-1 cells (Korean cell line bank, Seoul, Korea) were grown in RPMI-1640 media (Welgene Inc., Daegu, Korea) with $10 \mathrm{mM}$ HEPES buffer (Invitrogen Corp., Gibco BRL, MD, USA) and $\beta$ mercaptoethanol (Invitrogen Corp.) supplemented with 10\% heat-inactivated fetal bovine serum and $1 \%$ antibioticantimycotic (Invitrogen Corp.). The cells were maintained at $37^{\circ} \mathrm{C}$ in a $5 \% \mathrm{CO}_{2}$ humidified incubator.

2.2. NF- $\kappa B / A P-1$ Activation Reporter Assay. NF- $\kappa \mathrm{B}$ activation was measured using THP-1-Xblue cells, which are reporter cells expressing the embryonic alkaline phosphatase gene under the control of a promoter inducible by the transcription factors, NF- $\kappa$ B and AP-1. Cells were seeded in 24-well culture plates at $0.8 \times 10^{6}$ cells/well or 96 -well culture plates at $2 \times$ $10^{5}$ cells/well and preincubated for $2 \mathrm{~h}$ with or without the Hsp90 inhibitor geldanamycin (GA) or the Hsp70 inhibitor VER155008, followed by stimulation with 10 and $100 \mathrm{ng} / \mathrm{ml}$ of flagellin for $24 \mathrm{~h}$. A $20 \mu \mathrm{l}$ aliquot of the supernatant was collected from flagellin-stimulated cultures and then added to $180 \mu \mathrm{l}$ of QUANTI-Blue alkaline phosphatase detection medium (InvivoGen, USA) for color development at $37^{\circ} \mathrm{C}$. After 2-h color development, absorbance was measured at $630 \mathrm{~nm}$ using an ELISA microplate reader ( $\mu$-Quant; Bio-Tek Instruments, Winooski, USA).

2.3. Treatment of Cells with Inhibitors. The Hsp90 inhibitor, GA, was purchased from Sigma-Aldrich (St. Louis, MO, USA). Cells were treated with different concentrations of GA $(5,10,20,50,100,200$, and $500 \mathrm{nM})$ for $24 \mathrm{~h}$. 17-(Allylamino)17-demethoxygeldanamycin (17-AAG) and radicicol were purchased from Cayman Chemical (Ann Arbor, MI, USA). Cells were treated with different concentrations of each Hsp90 inhibitor, according to specific treatments. The Hsp70 inhibitor, VER155008, was obtained from Sigma-Aldrich.

2.4. Flow Cytometry. To determine the surface expression of TLR5, cells were incubated with a purified anti-TLR5 antibody (MA5-16236, Thermo Fisher Scientific, Waltham, MA, USA) for $30 \mathrm{~min}$ and then incubated with phycoerythrinconjugated secondary antibody (goat IgG; CLCC35004; Cedarlane Lab, Burlington, Ontario, Canada) at $4^{\circ} \mathrm{C}$ for $30 \mathrm{~min}$. After washing with phosphate buffered saline (PBS), cells were resuspended in PBS before analysis on a Cytomics FC500 MLP (Beckman Coulter Inc., Fullerton, CA, USA). To determine intracellular TLR5 expression, cells were incubated with $50 \mu \mathrm{l}$ of fixation buffer for $30 \mathrm{~min}$ at room temperature followed by $30 \mathrm{~min}$ incubated with $50 \mu \mathrm{l}$ of $1 x$ permeabilization buffer. Cells were then stained with a purified anti-TLR5 antibody (19D759.2, Novus Biologicals, Littleton, Colorado, USA) for $30 \mathrm{~min}$ and then incubated with phycoerythrin-conjugated secondary antibody (goat IgG; CLCC35004; Cedarlane Lab) at $4^{\circ} \mathrm{C}$ for $30 \mathrm{~min}$. After washing with PBS, cells were resuspended in PBS before analysis on a Cytomics FC500 MLP (Beckman Coulter Inc.).
2.5. Quantitative Real-Time Polymerase Chain Reaction (PCR). In order to analyze TLR5 expression, total RNA was extracted with the Qiagen RNeasy kit (Qiagen) according to the manufacturer's instructions. RNA concentrations were determined with a MaestroNano Micro-Volume Spectrophotometer (Maestrogen, Las Vegas, NV, USA). cDNA was synthesized from $2 \mu \mathrm{g}$ of total RNA using Hyperscript RT master mix (GeneAll, Seoul, Korea) using an Oligo (dT) primer (Invitrogen) at $42^{\circ} \mathrm{C}$ for $1 \mathrm{~h}$.

Quantitative real-time PCR was performed on the rotorgene system (Qiagen) using the Platinum SYBR Green qPCR SuperMix-UDG (Invitrogen). PCR amplification was performed using the following primer sets: TLR $55^{\prime}$-ccttacagcgaacctcatccac- $3^{\prime}, 5^{\prime}$-tccactacaggaggagaagcga- $3^{\prime}, \beta$ actin $5^{\prime}$-gacttccctactctcatctgct- $3^{\prime}, 5^{\prime}$-cttattctaggggcagagggt$3^{\prime}$. Sample normalization was performed using the human $\beta$ actin gene as an endogenous control. For each sample, the relative abundance of target mRNA was calculated from the $\mathrm{C}_{\Delta \mathrm{t}}$ values of the target and endogenous $\beta$-actin reference genes using the $2^{-\Delta \Delta}$ cycle threshold $(\mathrm{Ct})$ method.

2.6. Western Blot Analysis. For NF- $\kappa$ B activation, nuclear and cytoplasmic proteins were separated using NucBuster Protein Extraction Kit (Novagen, Rockland, USA). Proteins were separated on $8 \%$ SDS-polyacrylamide gels and transferred onto PVDF membranes. After blocking with 5\% BSA solution, the membranes were incubated overnight with primary antibody against NF- $\kappa$ B p 65 (sc-372, Santa Cruz) at $4^{\circ} \mathrm{C}$. Subsequently, the membrane was washed using TBS with Tween (TBST) and then incubated with secondary antibody solutions at room temperature for $2 \mathrm{hr}$. Blots were again washed with TBST and then developed with the ECL Plus Western Blotting Detection System. $\beta$-Actin and lamin B were used as positive control for the cytoplasmic and nuclear proteins, respectively.

For TLR5, THP-1 cells were treated with GA at different concentrations $(20,50,100200$, and $500 \mathrm{nM})$. The same procedure of Western blot analysis as described above was performed with an anti-TLR5 antibody (19D759.2, Novus Biologicals).

2.7. Statistical Analysis. Data were analyzed by one-way analysis of variance (ANOVA) followed by post hoc comparisons either with the Tukey HSD (honestly significant difference test) for groups of data with equal variances or with the Games-Howell test for unequal variances using SPSS 12.0 for Windows. All experiments were performed in duplicate. Data from two independent experiments with different batches were pooled for statistical analysis. Values are expressed as means \pm standard deviation (SD). Statistical significance was defined as $P<0.05$.

\section{Results}

3.1. Hsp90 and 70 Inhibitors Decrease Flagellin-Induced NF$\kappa B / A P-1$ Activity of THP-1. To find whether inhibition of Hsp90 may affect flagellin-induced activation of human myeloid leukemia cells, bacterial flagellin-induced NF- $\kappa \mathrm{B}$ activation of THP- 1 cells in the presence of Hsp90 inhibitor was examined by NF- $\kappa \mathrm{B} / \mathrm{AP}-1$ reporting assay. Cells were 


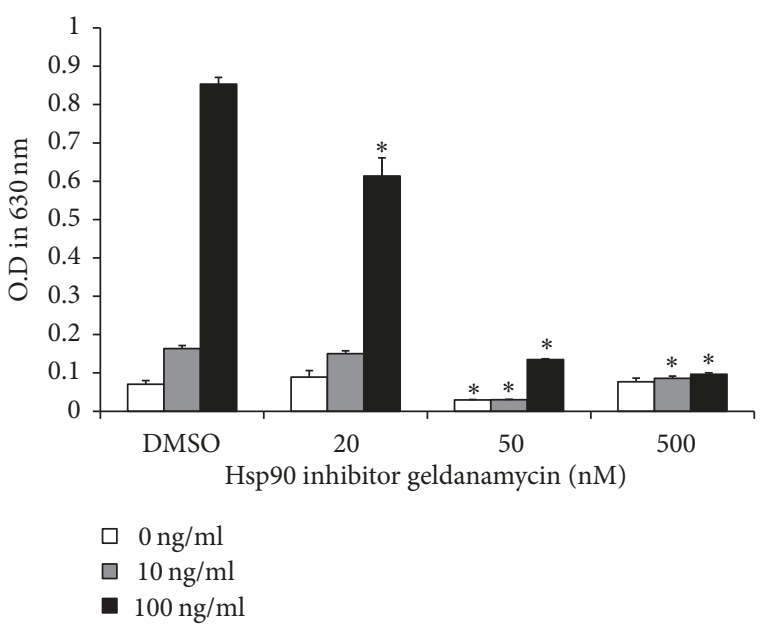

(a)

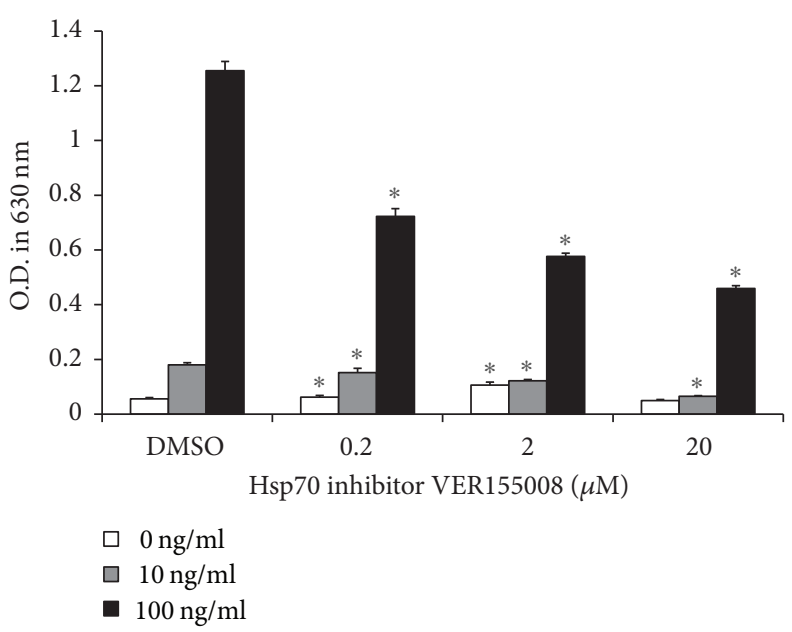

(b)

Figure 1: Inhibition of Hsp90 and Hsp70 decreases flagellin-induced NF- $\kappa$ B/AP-1 activity in THP-1-Xblue cells. (a) THP-1-Xblue cells were preincubated for $2 \mathrm{~h}$ with (a) 20, 50, and $500 \mathrm{nM}$ of the Hsp90 inhibitor GA or (b) $0.2,2$, and $20 \mu \mathrm{M}$ of the Hsp70 inhibitor VER155008 followed by stimulation with 0 (white), 10 (gray), and $100 \mathrm{ng} / \mathrm{ml}$ (black) flagellin from Salmonella typhimurium for $24 \mathrm{~h}$. After stimulation, the supernatant was collected and mixed with QUANTI-Blue solution for color development at $37^{\circ} \mathrm{C}$. After 2-h color development, absorbance was measured by an ELISA microplate reader at $630 \mathrm{~nm}$. Bar graphs indicate means $\pm \mathrm{SD}(n=6) .{ }^{*} P<0.01$ versus DMSO-treated group.

preincubated with Hsp90 inhibitor geldanamycin (GA) with various concentrations for $2 \mathrm{~h}$, followed by $24 \mathrm{~h}$ stimulation with 0,10 , or $100 \mathrm{ng} / \mathrm{ml}$ of flagellin. Flagellin-induced NF$\kappa \mathrm{B} / \mathrm{AP}-1$ activity was significantly reduced by the treatment of $50 \mathrm{nM}$ and $500 \mathrm{nM}$ GA compared to the control (Figure 1(a)). Inhibitory effects of $20 \mathrm{nM}$ GA on NF- $\kappa \mathrm{B} / \mathrm{AP}-1$ activity were found at the only $100 \mathrm{ng} / \mathrm{ml}$ flagellin-treated group (Figure 1(a)). Since it is known that Hsp70 acts as a cochaperone of Hsp90 [26], we also examined the effect of Hsp70 inhibition on flagellin-induced NF- $\kappa \mathrm{B} / \mathrm{AP}-1$ activity using Hsp70 inhibitor, VER155008, at the concentrations ranging from 0.2 to $2 \mu \mathrm{M}$ (Figure 1(b)). Flagellin-induced NF- $\kappa \mathrm{B} / \mathrm{AP}-$ 1 activity was reversed in cells treated with VER155008. However, Hsp70 inhibitor showed less inhibitory potency compared with Hsp90 inhibitor (Figure 1(b)).

Since previous study has reported that Hsp90 activity is required for $\mathrm{I} \kappa \mathrm{B}$ kinase biosynthesis and $\mathrm{NF}-\kappa \mathrm{B}$ activation [27], we examined baseline expression of NF- $\kappa$ B in THP-1 cells treated with various concentrations of GA. As shown in Figure 2, basal expression levels of both cytoplasmic and nuclear NF- $\kappa \mathrm{B}$ p 65 were not significantly changed by treatment of GA, suggesting that GA treatment does not directly affect baseline levels of NF- $\kappa \mathrm{B}$ in THP-1 cells under our experimental conditions.

\subsection{Hsp90 Inhibitor Enhances TLR5 mRNA Expression,} While Reducing Cell Surface TLR5. Next, we examined the effects of various concentrations of GA ranging from $20 \mathrm{nM}$ to $500 \mathrm{nM}$ on TLR5 mRNA expression using a quantitative real-time PCR analysis. TLR5 mRNA expression started to increase with concentration as low as $20 \mathrm{nM}$ and reached its maximal (nearly 25 -fold) increase with $500 \mathrm{nM}$ GA (Figure 3(a)). TLR5 mRNA upregulation started $2 \mathrm{~h}$, reaching approximately 25 times the control level at $24 \mathrm{~h}$ after treatment with 500 nM GA (Figure 3(b)).

In an attempt to elucidate the mechanism by which Hsp90 inhibitor causes the reduction in NF- $\kappa$ B/AP-1 activity induced by flagellin in the THP-1 cells, surface expression levels of TLR 5 were evaluated after GA treatment. As shown in Figure 4(a), GA exhibited suppressive effects on surface TLR5 expression in a concentration dependent manner. This effect was further confirmed by other Hsp90 inhibitors, such as 17-AAG and radicicol. Like GA, these inhibitors also caused the reduction in cell surface TLR 5 expression in concentration dependent manner (Figures 4(b) and 4(c)).

To explain the apparent discrepancy between reduction in TLR5 surface expression and increased mRNA expression, we examined total protein levels of TLR5 of THP-1 cells treated with various concentrations of GA by both flow cytometry and Western blot analysis. Similar to surface TLR5 expressions, total protein levels of TLR5 were significantly decreased by GA treatment in a concentration dependent manner (Figure 5).

3.3. Inhibition of Hsp70 Enhances TLR5 mRNA Expression, While Reducing Cell Surface TLR5. Since HSP70 proteins work closely with the HSP90 molecules to maintain the stability and activities of their client proteins [26], we investigated the effects of Hsp70 inhibition on TLR5 expression of THP-1. Cells were treated with or without Hsp70 inhibitor VER155008 and TLR5 mRNA expression was examined. Like GA, Hsp70 inhibitor increased the level of TLR5 mRNA expression (Figure 6(a)), whereas it decreased cell surface TLR5 expression (Figure 6(b)). However, the increase in TLR5 mRNA expression and the reduction in cell surface TLR5 expression by Hsp70 inhibitor were much less than those by Hsp90 inhibitor. 

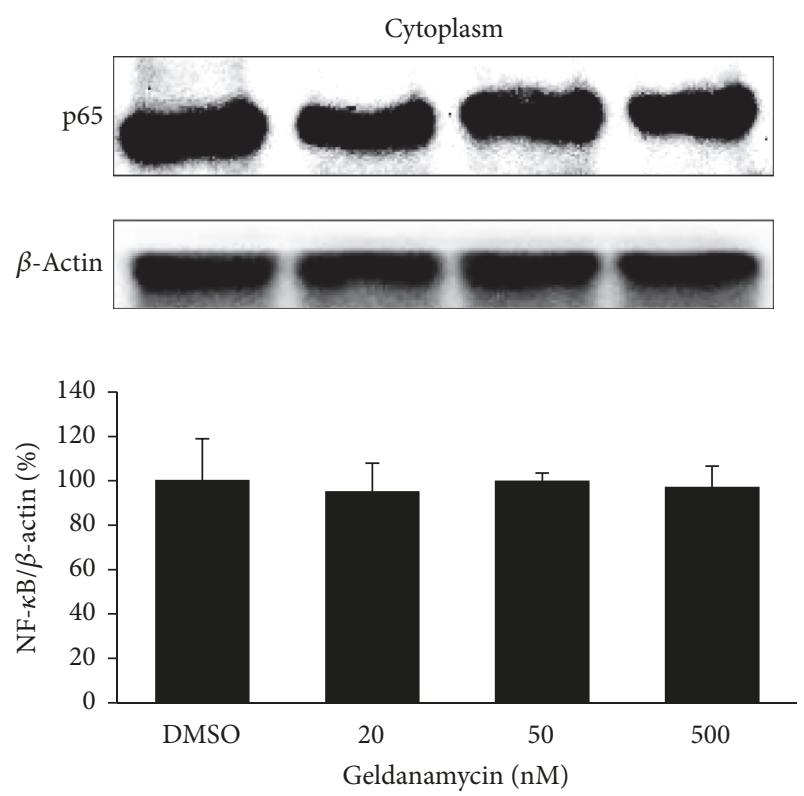

(a)

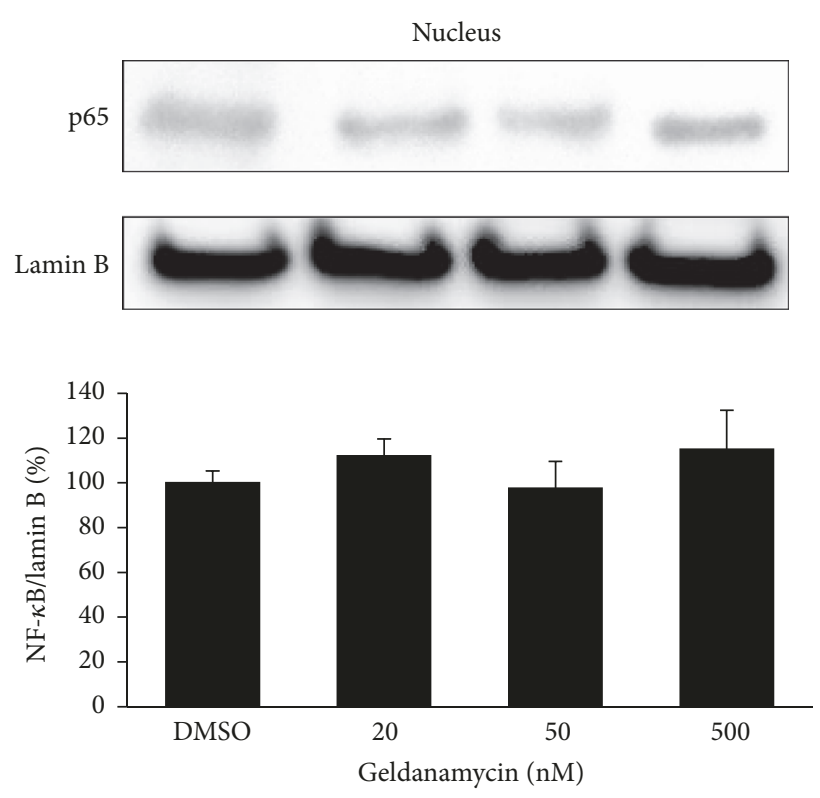

(b)

Figure 2: GA does not affect basal levels of p65 protein in both cytoplasmic and nuclear fractions of THP-1 cells. Cells were treated with or without the Hsp90 inhibitor GA (20, 50, and $500 \mathrm{nM}$ ) for $24 \mathrm{hr}$. The levels of NF- $\kappa \mathrm{B}$ p65 expression in the cytoplasm (a) and nucleus (b) were measured by Western blotting analysis. $\beta$-Actin was used as a cytoplasm marker and lamin B as a nuclear marker. Data are expressed as means of relative expression ratio $\pm \mathrm{SD}(n=3)$.

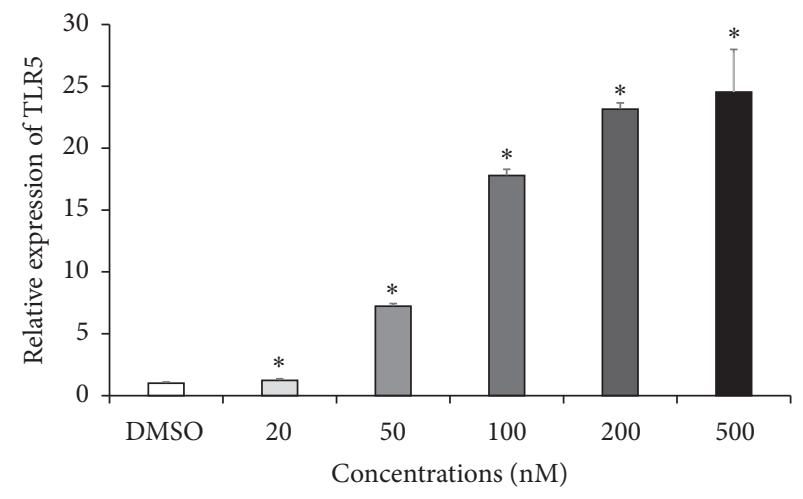

(a)

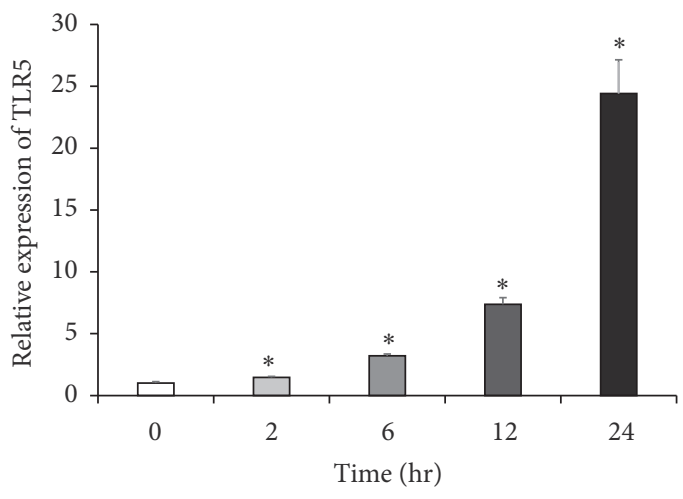

(b)

FIGURE 3: GA enhances TLR5 mRNA expression in concentration- and time-dependent manners. Gene expression of TLR5 was determined by qRT-PCR and was normalized to that of $\beta$-actin. THP-1 cells were treated with or without the Hsp90 inhibitor GA (a) at various concentrations for $24 \mathrm{~h}$ or (b) at various time points. Data are expressed as means of relative expression ratio $\pm \mathrm{SD}(n=6) .{ }^{*} P<0.05$ versus DMSO-treated group.

\section{Discussion}

In the present study, we demonstrated that Hsp90 or Hsp70 inhibitors suppress flagellin-induced NF- $\kappa \mathrm{B}$ activation in the human myeloid leukemia cell line THP-1. The reduction in cell surface expression of TLR5 caused by Hsp90 or Hsp70 inhibition was found to be responsible for this reduced activity. Although we do not yet know reasons for the perfect negative correlation between mRNA and protein levels of TLR5 seen in the present study, considering the chaperoning function of Hsps, inhibition of Hsp90 or Hsp70 could interfere with proper folding of TLR5, which inhibits movement of mature TLR5 molecules from the endoplasmic reticulum (ER) to the cell surface. In particular, since gp96, an ER paralog of Hsp90 [28], is the master immune chaperone for both cell surface and intracellular TLRs, including TLRs 1 , $2,4,5,7$, and 9 [29], inhibition of gp96 by GA [30] can cause reduction in TLR5 surface expression. This may explain why Hsp90 inhibitors exerted more potent inhibitory effects than the Hsp70 inhibitor. However, to confirm our speculation that the reduction in the levels of newly synthesized TLR5 proteins is largely due to consequences of ER quality control 


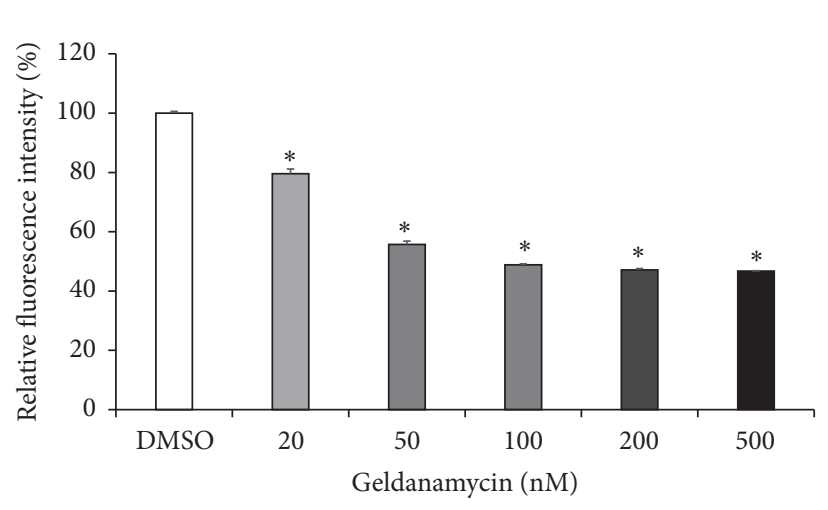

(a)

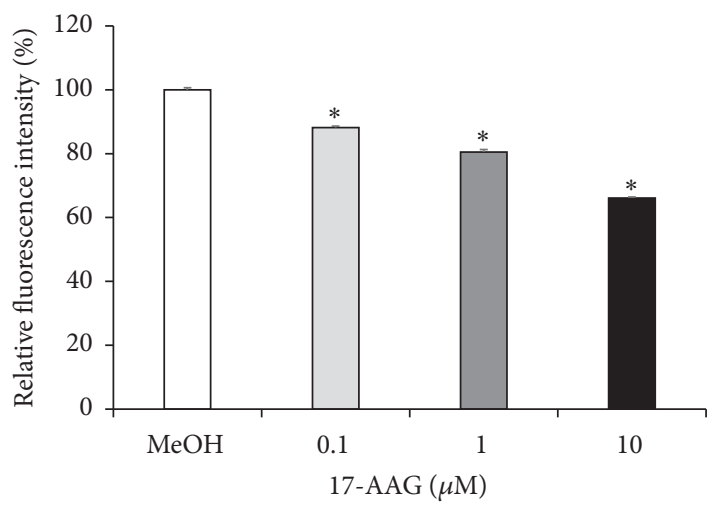

(b)

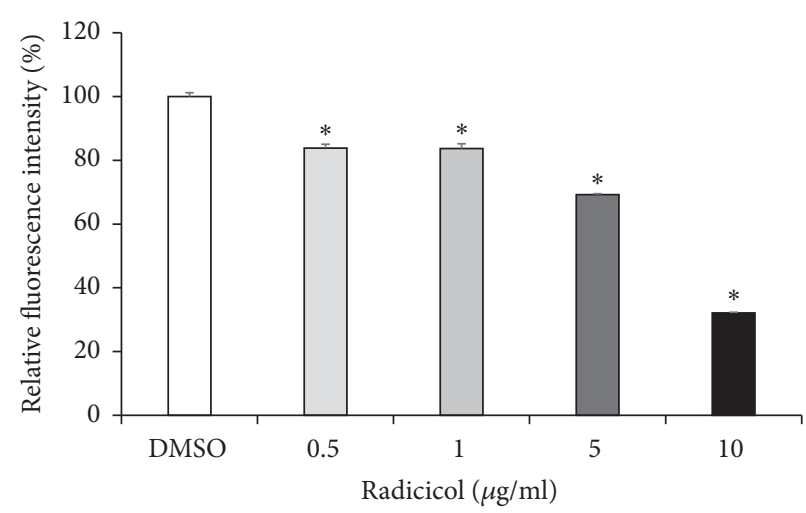

(c)

FIGURE 4: Inhibition of Hsp90 reduces TLR5 cell surface expression. Cell surface expression of TLR5 in THP-1 cells was examined by flow cytometry analysis. THP-1 cells were treated with or without the Hsp90 inhibitors, (a) GA, (b) 17-AAG, and (c) radicicol at various concentrations for $24 \mathrm{~h}$. Relative fluorescence intensity was measured, and data are expressed as means of relative expression ratio $\pm \mathrm{SD}$ $(n=6) .{ }^{*} \mathrm{P}<0.05$ versus DMSO- or MeOH-treated group.

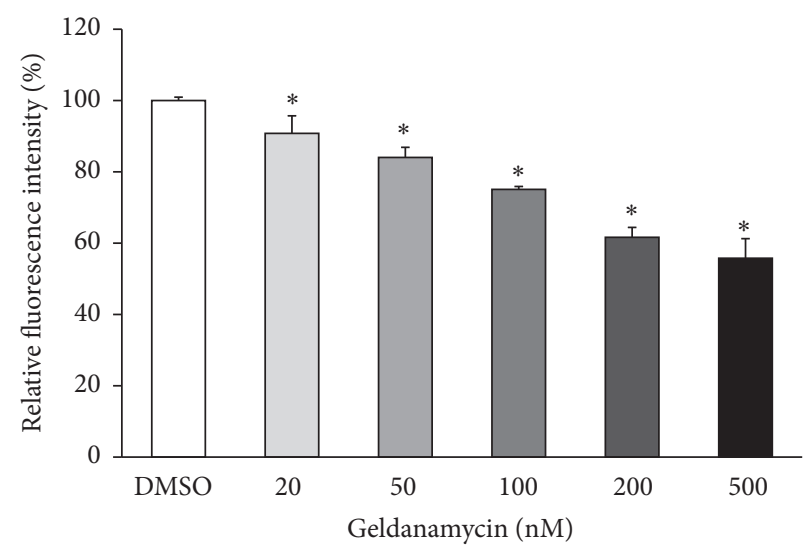

(a)
TLR5
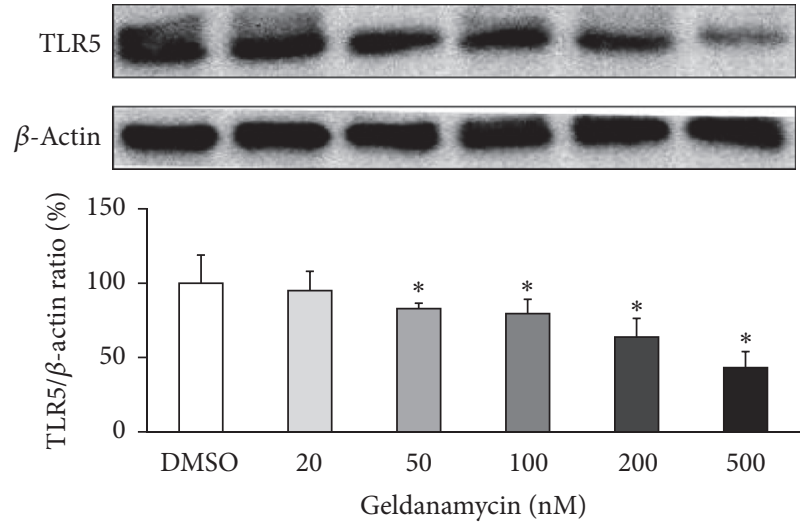

(b)

FIGURE 5: Inhibition of Hsp90 reduces total protein levels of TLR5. THP-1 cells were treated with or without the Hsp90 inhibitor GA (20, 50, 100,200 , and $500 \mathrm{nM}$ ) for $24 \mathrm{hr}$. The levels of TLR5 protein expression were measured by intracellular flow cytometry (a) or Western blot (b). Shown are representative blots and densitometric ratios of proteins normalized to $\beta$-actin. Data are expressed as means of relative expression ratio $\pm \mathrm{SD}(n=3$ or 4$) .{ }^{*} P<0.05$ versus DMSO-treated group. 


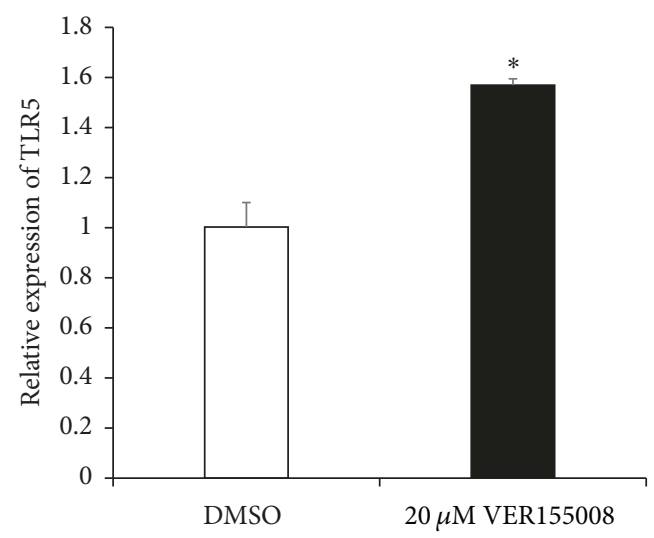

(a)

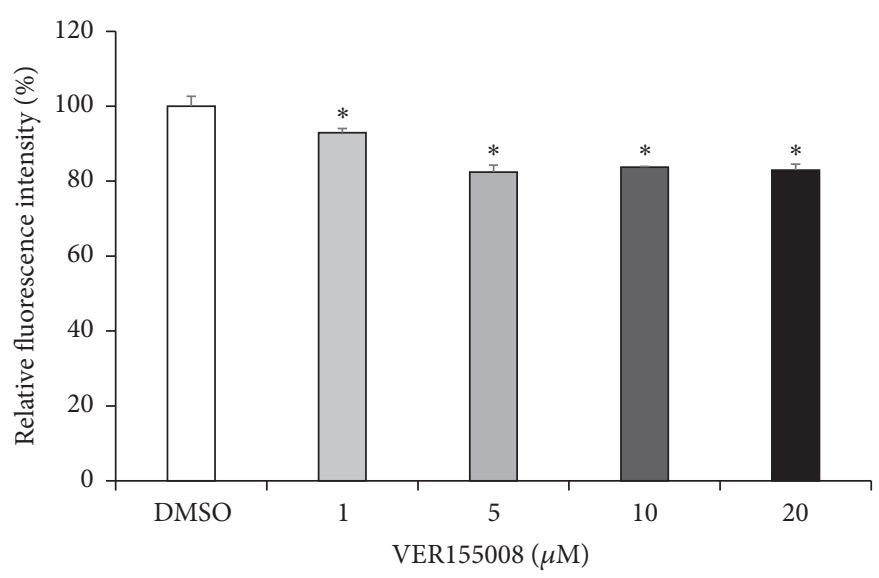

(b)

FIGURE 6: Inhibition of Hsp70 enhances TLR5 mRNA expression, while reducing TLR5 surface expression. (a) The Hsp70 inhibitor VER155008 enhances TLR5 mRNA expression in THP-1 cells. Gene expression of TLR5 was determined by qRT-PCR and was normalized to that of $\beta$-actin. THP-1 cells were treated with or without $20 \mu \mathrm{M}$ VER155008 for $24 \mathrm{~h}$. Data are expressed as means of relative expression ratio \pm SD $(n=6) .{ }^{*} P<0.05$ versus DMSO-treated group. (b) Cell surface expression of TLR5 in THP-1 cells was examined by flow cytometry analysis. THP-1 cells were treated with or without VER155008, at various concentrations, for $24 \mathrm{~h}$. Relative fluorescence intensity was measured, and data are expressed as relative TLR5 expression $\pm \mathrm{SD}(n=6) .{ }^{*} P<0.05$ versus DMSO-treated group.

mechanisms in the presence of Hsp90 inhibitor, it is necessary to examine ER-associated protein degradation, which is a process for detecting and removing misfolded proteins [31], in future study. Regarding the reasons for increased mRNA levels of TLR5, we cautiously speculate that cells treated with Hsp inhibitors may upregulate TLR5 mRNA expression to compensate for the loss of the TLR5 proteins.

Innate immune cells can recognize various tumorderived antigens through TLRs [32]. Thus, TLR-mediated activation of innate immune cells might play a role in counteracting tumor cells [33]. Indeed, much attention has been recently paid to tumor immunotherapy, which uses TLR agonists to enhance the sensitivity of innate immune cells to tumor-derived antigens [34]. Several TLR agonists have been investigated under preclinical and clinical evaluation $[35,36]$, and some TLR agonists have been approved for use in tumor therapy [37-41]. However, the current barrier to effective tumor treatment is that the tumor itself is highly immunosuppressive to innate immune responses [42]. Tumor cells and tissues also express TLRs, and elevated expression of TLRs promotes tumor cell survival and proliferation [43, 44]. Furthermore, persistent activation of TLR signaling and the resultant proinflammatory microenvironment facilitate tumor progression and immune suppression by decreasing the cytotoxicity of immune cells, increasing the production of proinflammatory factors, and metastasis [43, 45-47]. Thus, targeting the expression and activation of TLRs in tumor cells might be an important therapeutic strategy to treat tumor. In this regard, our results, showing that treatment with Hsp90 inhibitors induced the suppression of TLR5 cell surface expression and NF- $\kappa \mathrm{B}$ activation in THP-1 cells, suggest that Hsp90 inhibitors could be useful to treat tumors, especially human myeloid leukemia that was previously reported to be associated with enhanced TLR5 expression and signaling [24].
The Hsp90 inhibitors used in this study are pan-inhibitors that have limitation to elucidate the role of particular isoforms of Hsp90. Therefore, the use of selective inhibitor of particular isoform of Hsp90 would be necessary to understand the role of each isoform in the modulation of TLR5 expression and flagellin-induced NF- $\kappa \mathrm{B} / \mathrm{AP}-1$ activity in future study. In addition, the effects of Hsp70 inhibitors should be more fully explored in future study.

In summary, our results show for the first time that Hsp90 inhibitors suppress TLR5 surface expression and subsequently inhibit NF- $\kappa \mathrm{B}$ activation in human myeloid leukemia THP-1 cells. We suggest that these inhibitory effects may be associated with the possible mechanisms by which Hsp90 inhibitors suppress myeloid leukemia.

\section{Conflicts of Interest}

The authors declare that they have no conflicts of interest.

\section{Acknowledgments}

This research was supported by Basic Science Research Program through the National Research Foundation of Korea (NRF) funded by the Ministry of Education (NRF2015R1D1A1A01059876).

\section{References}

[1] L. H. Pearl and C. Prodromou, "Structure and in vivo function of Hsp90," Current Opinion in Structural Biology, vol. 10, no. 1, pp. 46-51, 2000.

[2] F. Burrows, H. Zhang, and A. Kamal, "Hsp90 activation and cell cycle regulation," Cell Cycle, vol. 3, no. 12, pp. 1530-1536, 2004.

[3] M. Taipale, D. F. Jarosz, and S. Lindquist, "HSP90 at the hub of protein homeostasis: emerging mechanistic insights," Nature Reviews Molecular Cell Biology, vol. 11, no. 7, pp. 515-528, 2010. 
[4] R. Zhao, M. Davey, Y.-C. Hsu et al., "Navigating the chaperone network: an integrative map of physical and genetic interactions mediated by the Hsp90 chaperone," Cell, vol. 120, no. 5, pp. 715727, 2005.

[5] A. J. McClellan, Y. Xia, A. M. Deutschbauer, R. W. Davis, M. Gerstein, and J. Frydman, "Diverse cellular functions of the Hsp90 molecular chaperone uncovered using systems approaches," Cell, vol. 131, no. 1, pp. 121-135, 2007.

[6] L. Whitesell and S. L. Lindquist, "HSP90 and the chaperoning of cancer," Nature Reviews Cancer, vol. 5, no. 10, pp. 761-772, 2005.

[7] L. Whitesell, E. G. Mimnaugh, B. de Costa, C. E. Myers, and L. M. Neckers, "Inhibition of heat shock protein HSP90pp60v-src heteroprotein complex formation by benzoquinone ansamycins: essential role for stress proteins in oncogenic transformation," Proceedings of the National Acadamy of Sciences of the United States of America, vol. 91, no. 18, pp. 8324-8328, 1994.

[8] P. George, P. Bali, P. Cohen et al., "Cotreatment with 17allylamino-demethoxygeldanamycin and FLT-3 kinase inhibitor PKC412 is highly effective against human acute myelogenous leukemia cells with mutant FLT-3," Cancer Research, vol. 64, no. 10, pp. 3645-3652, 2004.

[9] L. Shang and T. B. Tomasi, "The heat shock protein 90-CDC37 chaperone complex is required for signaling by types I and II interferons," The Journal of Biological Chemistry, vol. 281, no. 4, pp. 1876-1884, 2006.

[10] M. B. Laederich, C. R. Degnin, G. P. Lunstrum, P. Holden, and W. A. Horton, "Fibroblast Growth Factor Receptor 3 (FGFR3) is a strong Heat shock protein 90 (Hsp90) client: Implications for therapeutic manipulation," The Journal of Biological Chemistry, vol. 286, no. 22, pp. 19597-19604, 2011.

[11] N. Miyajima, S. Tsutsumi, C. Sourbier et al., "The HSP90 inhibitor ganetespib synergizes with the MET kinase inhibitor crizotinib in both crizotinib-sensitive and -resistant METdriven tumor models," Cancer Research, vol. 73, no. 23, pp. 7022-7033, 2013.

[12] R. Garcia-Carbonero, A. Carnero, and L. Paz-Ares, "Inhibition of HSP90 molecular chaperones: moving into the clinic," The Lancet Oncology, vol. 14, no. 9, pp. e358-e369, 2013.

[13] T. Taldone, H. J. Patel, A. Bolaender, M. R. Patel, and G. Chiosis, "Protein chaperones: a composition of matter review (2008-2013)," Expert Opinion on Therapeutic Patents, vol. 24, no. 5, pp. 501-518, 2014.

[14] A. Iwasaki and R. Medzhitov, "Toll-like receptor control of the adaptive immune responses," Nature Immunology, vol. 5, no. 10, pp. 987-995, 2004.

[15] E. N. Hatada, D. Krappmann, and C. Scheidereit, "NF- $\kappa$ B and the innate immune response," Current Opinion in Immunology, vol. 12, no. 1, pp. 52-58, 2000.

[16] B. L. Esplin, T. Shimazu, R. S. Welner et al., "Chronic exposure to a TLR ligand injures hematopoietic stem cells," The Journal of Immunology, vol. 186, no. 9, pp. 5367-5375, 2011.

[17] Y. Zhao, F. Ling, H.-C. Wang, and X.-H. Sun, "Chronic TLR signaling impairs the long-term repopulating potential of hematopoietic stem cells of wild type but not Id1 deficient mice," PLoS ONE, vol. 8, no. 2, Article ID e55552, 2013.

[18] C. I. Maratheftis, E. Andreakos, H. M. Moutsopoulos, and M. Voulgarelis, "Toll-like receptor-4 is up-regulated in hematopoietic progenitor cells and contributes to increased apoptosis in myelodysplastic syndromes," Clinical Cancer Research, vol. 13, no. 4, pp. 1154-1160, 2007.

[19] W. K. Hofmann, S. De Vos, M. Komor, D. Hoelzer, W. Wachsman, and H. Phillip Koeffler, "Characterization of gene expression of $\mathrm{CD}^{+} 4^{+}$cells from normal and myelodysplastic bone marrow," Blood, vol. 100, no. 10, pp. 3553-3560, 2002.

[20] M. E. Varney, M. Niederkorn, H. Konno et al., "Loss of Tifab, a del(5q) MDS gene, alters hematopoiesis through derepression of Toll-like receptor-TRAF6 signaling," The Journal of Experimental Medicine, vol. 212, no. 11, pp. 1967-1985, 2015.

[21] D. T. Starczynowski, F. Kuchenbauer, and B. Argiropoulos, "Identification of miR-145 and miR-146a as mediators of the 5qsyndrome phenotype," Nature Medicine, vol. 16, no. 1, pp. 49-58, 2010.

[22] Y. Wei, S. Dimicoli, C. Bueso-Ramos et al., "Toll-like receptor alterations in myelodysplastic syndrome," Leukemia, vol. 27, no. 9, pp. 1832-1840, 2013.

[23] S. Dimicoli, Y. Wei, C. Bueso-Ramos et al., "Overexpression of the Toll-Like Receptor (TLR) Signaling Adaptor MYD88, but Lack of Genetic Mutation, in Myelodysplastic Syndromes," PLoS ONE, vol. 8, no. 8, Article ID e71120, 2013.

[24] M. Okamoto, H. Hirai, K. Taniguchi et al., “Toll-like Receptors (TLRs) are expressed by myeloid leukaemia cell lines, but fail to trigger differentiation in response to the respective TLR ligands: Correspondence," British Journal of Haematology, vol. 147, no. 4, pp. 585-587, 2009.

[25] J. Bohnhorst, T. Rasmussen, S. H. Moen et al., "Toll-like receptors mediate proliferation and survival of multiple myeloma cells," Leukemia, vol. 20, no. 6, pp. 1138-1144, 2006.

[26] M. Triantafilou and K. Triantafilou, "Heat-shock protein 70 and heat-shock protein 90 associate with Toll-like receptor 4 in response to bacterial lipopolysaccharide," Biochemical Society Transactions, vol. 32, no. 4, pp. 636-639, 2004.

[27] M. Broemer, D. Krappmann, and C. Scheidereit, "Requirement of Hsp90 activity for I $\kappa \mathrm{B}$ kinase (IKK) biosynthesis and for constitutive and inducible IKK and NF- $\kappa \mathrm{B}$ activation," Oncogene, vol. 23, no. 31, pp. 5378-5386, 2004.

[28] Y. Yang and Z. Li, "Roles of heat shock protein gp96 in the ER quality control: Redundant or unique function?" Molecules and Cells, vol. 20, no. 2, pp. 173-182, 2005.

[29] Y. Yang, B. Liu, J. Dai et al., "Heat shock protein gp96 is a master chaperone for toll-like receptors and is important in the innate function of macrophages," Immunity, vol. 26, no. 2, pp. 215-226, 2007.

[30] C. Chavany, E. Mimnaugh, P. Miller et al., "p185erbB2 binds to GRP94 in vivo: Dissociation of the P185erbB2/GRP94 heterocomplex by benzoquinone ansamycins precedes depletion of p185erbB2," The Journal of Biological Chemistry, vol. 271, no. 9, pp. 4974-4977, 1996.

[31] R. Y. Hampton, "ER-associated degradation in protein quality control and cellular regulation," Current Opinion in Cell Biology, vol. 14, no. 4, pp. 476-482, 2002.

[32] P. Matzinger, "The danger model: a renewed sense of self," Science, vol. 296, no. 5566, pp. 301-305, 2002.

[33] A. Marcus, B. G. Gowen, T. W. Thompson et al., "Recognition of tumors by the innate immune system and natural killer cells," Advances in Immunology, vol. 122, pp. 91-128, 2014.

[34] T. Kottke, N. Boisgerault, R. M. Diaz et al., "Detecting and targeting tumor relapse by its resistance to innate effectors at early recurrence," Nature Medicine, vol. 19, no. 12, pp. 1625-1631, 2013.

[35] L. G. Burdelya, C. M. Brackett, B. Kojouharov et al., "Central role of liver in anticancer and radioprotective activities of Tolllike receptor 5 agonist," Proceedings of the National Acadamy of Sciences of the United States of America, vol. 110, no. 20, pp. E1857-E1866, 2013. 
[36] B. J. Weigel, S. Cooley, T. Defor et al., "Prolonged subcutaneous administration of $852 \mathrm{~A}$, a novel systemic toll-like receptor 7 agonist, to activate innate immune responses in patients with advanced hematologic malignancies," American Journal of Hematology, vol. 87, no. 10, pp. 953-956, 2012.

[37] H. W. Herr and A. Morales, "History of Bacillus CalmetteGuerin and Bladder Cancer: An Immunotherapy Success Story," The Journal of Urology, vol. 179, no. 1, pp. 53-56, 2008.

[38] R. Luckett and S. Feldman, "Impact of 2-, 4- and 9-valent HPV vaccines on morbidity and mortality from cervical cancer," Human Vaccines \& Immunotherapeutics, vol. 12, no. 6, pp. 13321342, 2016.

[39] M. Shi, X. Chen, K. Ye, Y. Yao, and Y. Li, "Application potential of toll-like receptors in cancer immunotherapy: Systematic review," Medicine, vol. 95, no. 25, p. e3951, 2016.

[40] A. K. Srivastava, G. Dinc, R. K. Sharma, E. S. Yolcu, H. Zhao, and H. Shirwan, "SA-4-1BBL and monophosphoryl lipid A constitute an efficacious combination adjuvant for cancer vaccines," Cancer Research, vol. 74, no. 22, pp. 6441-6451, 2014.

[41] S. Adams, L. Kozhaya, F. Martiniuk et al., "Topical TLR7 agonist imiquimod can induce immune-mediated rejection of skin metastases in patients with breast cancer," Clinical Cancer Research, vol. 18, no. 24, pp. 6748-6757, 2012.

[42] J. Fu, D. B. Kanne, M. Leong et al., "STING agonist formulated cancer vaccines can cure established tumors resistant to PD-1 blockade," Science Translational Medicine, vol. 7, no. 283, Article ID 283ra252, 2015.

[43] D. A. Monlish, S. T. Bhatt, and L. G. Schuettpelz, "The role of toll-like receptors in hematopoietic malignancies," Frontiers in Immunology, vol. 7, article no. 390, 2016.

[44] H. Tye, C. L. Kennedy, M. Najdovska et al., "STAT3-driven upregulation of TLR2 promotes gastric tumorigenesis independent of tumor inflammation," Cancer Cell, vol. 22, no. 4, pp. 466-478, 2012.

[45] B. Huang, J. Zhao, H. Li et al., "Toll-like receptors on tumor cells facilitate evasion of immune surveillance," Cancer Research, vol. 65, no. 12, pp. 5009-5014, 2005.

[46] R. Chen, A. B. Alvero, D.-A. Silasi, K. D. Steffensen, and G. Mor, "Cancers take their Toll - The function and regulation of Tolllike receptors in cancer cells," Oncogene, vol. 27, no. 2, pp. 225233, 2008.

[47] Y. Liu, W. Yan, S. Tohme et al., "Hypoxia induced HMGB1 and mitochondrial DNA interactions mediate tumor growth in hepatocellular carcinoma through Toll-like receptor 9," Journal of Hepatology, vol. 63, no. 1, article no. 5550, pp. 114-121, 2015. 


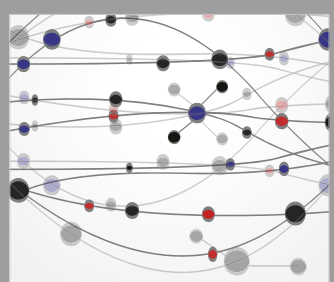

The Scientific World Journal
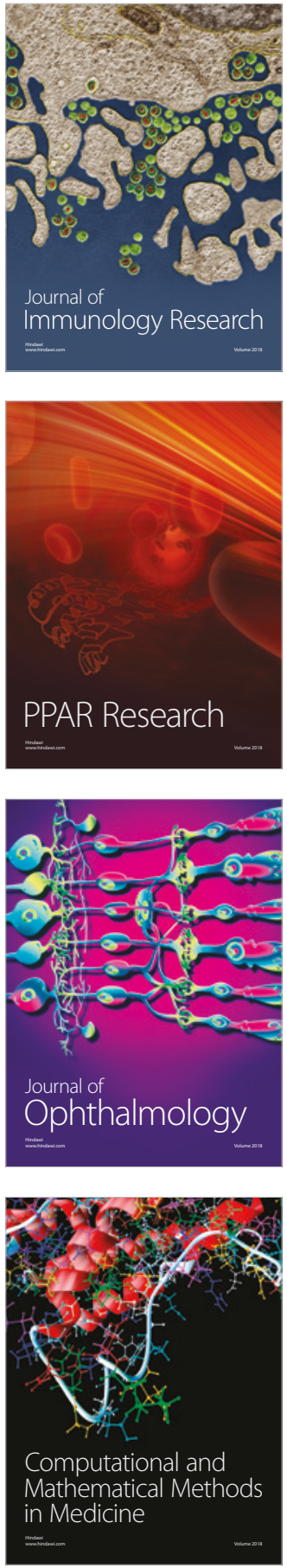

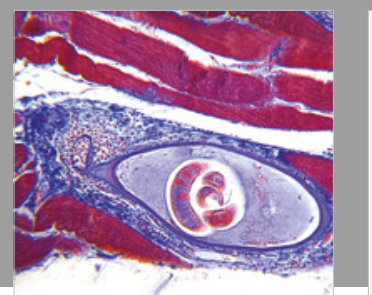

Gastroenterology Research and Practice

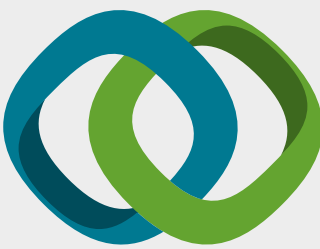

\section{Hindawi}

Submit your manuscripts at

www.hindawi.com
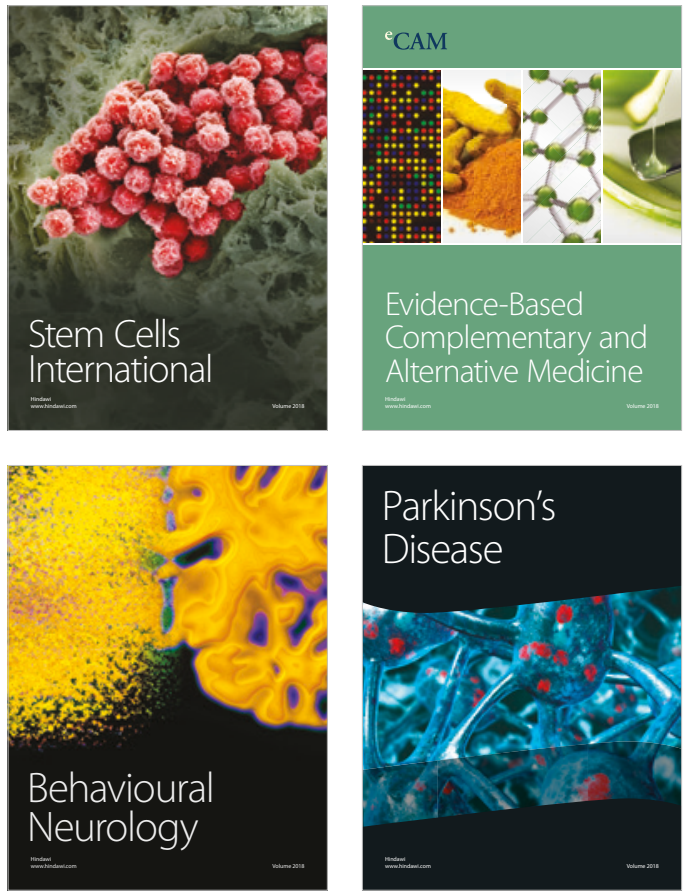

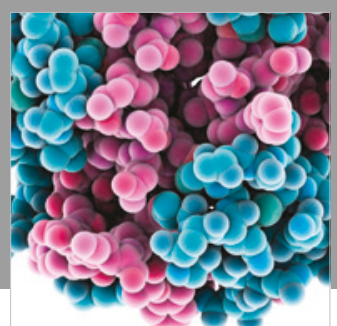

ournal of

Diabetes Research

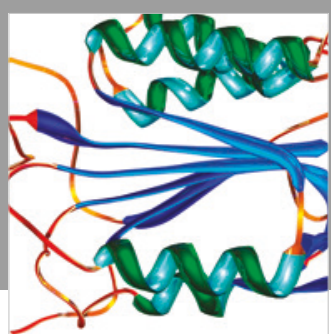

Disease Markers
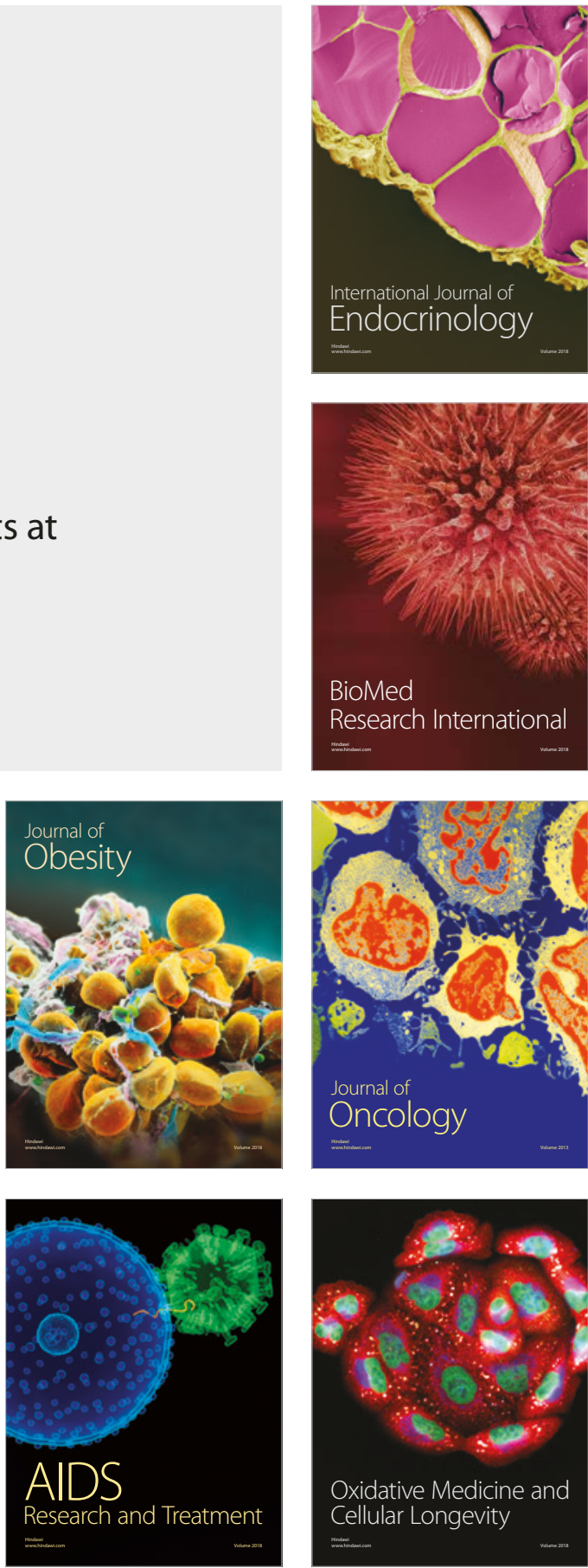